\title{
0000
}

Maurício Takashi Coutinho Watanabe
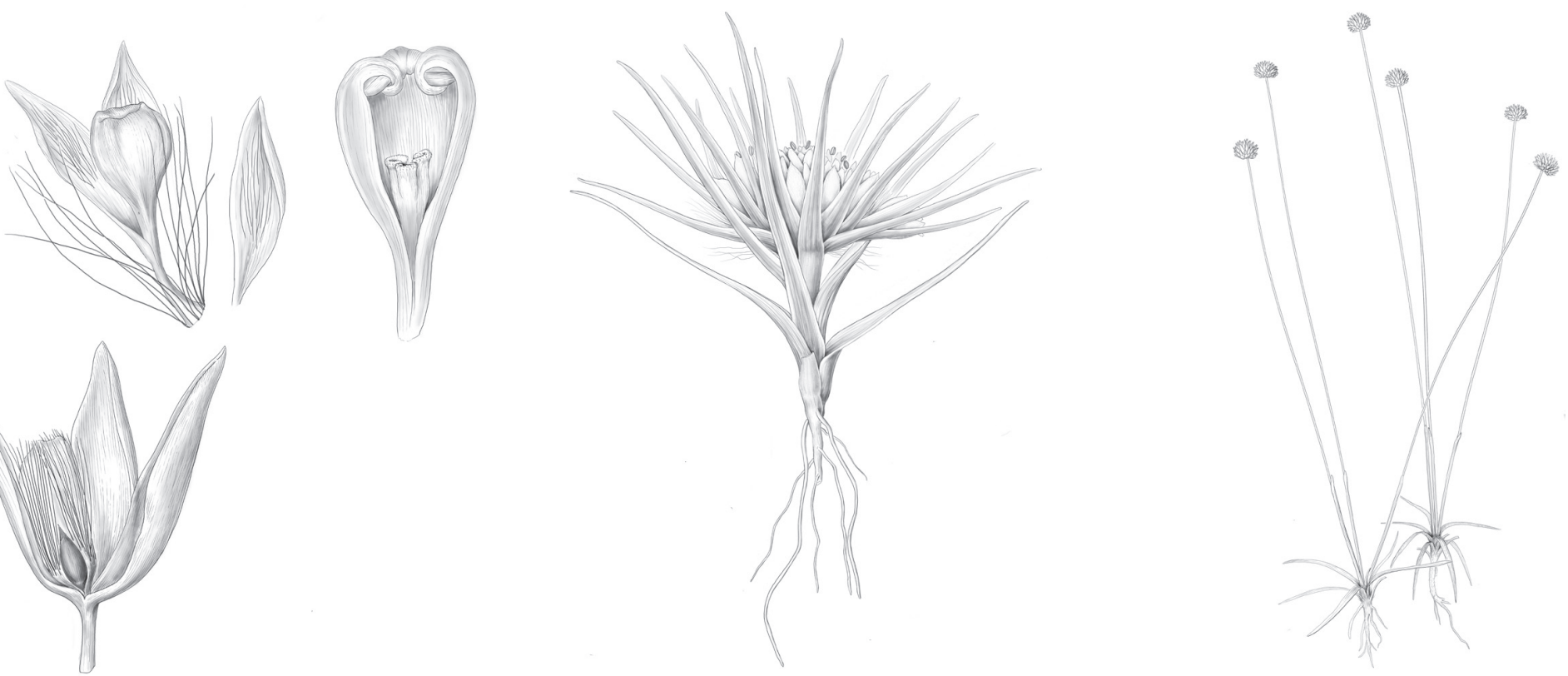

\section{Sistemática de Syngonanthus}

\section{(Eriocaulaceae)}
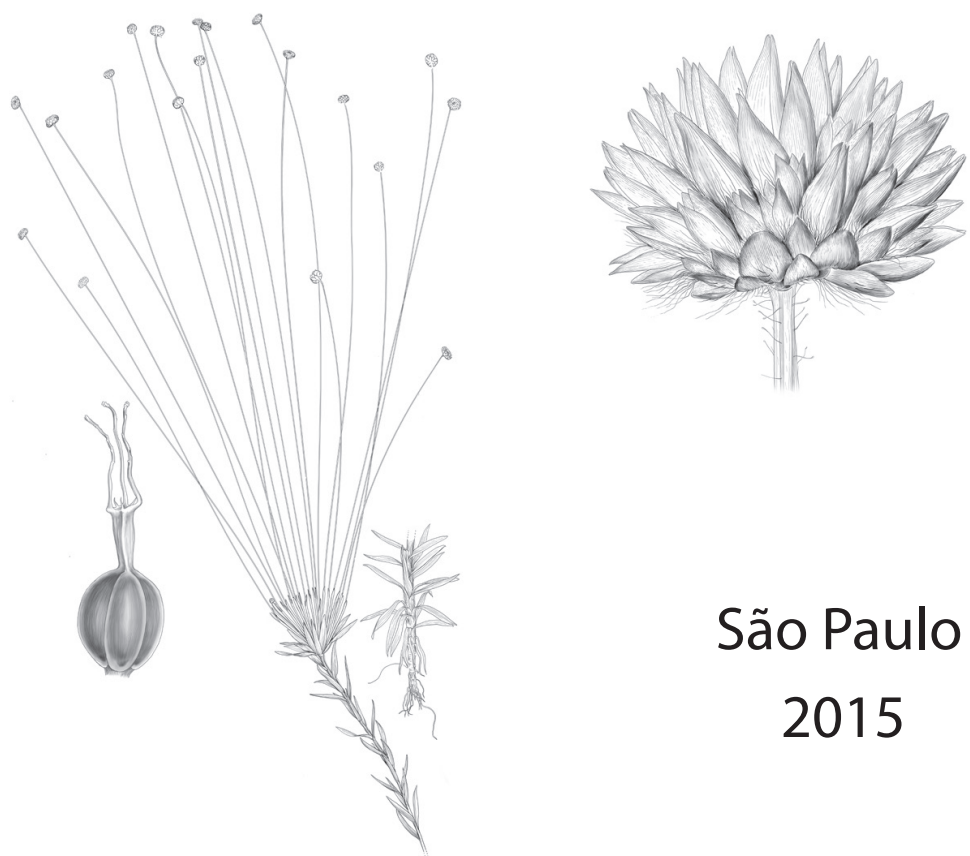

São Paulo 
Mauricio Takashi Coutinho Watanabe

\section{Sistemática de Syngonanthus}

\section{Systematics of Syngonanthus}

Tese apresentada ao Instituto de Biociências da Universidade de São Paulo, para a obtenção de Título de Doutor em Ciências, na Área de Botânica.

Orientador(a): Paulo Takeo Sano

São Paulo 


\section{Ficha Catalográfica}

Watanabe, Mauricio Takashi Coutinho

Sistemática de Syngonanthus

Número de páginas: 182

Tese (Doutorado) - Instituto de Biociências da Universidade de São Paulo. Departamento de Botânica.

1. Eriocaulaceae 2. Filogenia 3. Taxonomia. 4. Syngonanthus Universidade de São Paulo. Instituto de Biociências. Departamento de Botânica.

\section{Comissão Julgadora:}

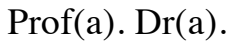

Prof(a). Dr(a).
Prof(a). Dr(a).

Prof(a). Dr(a).

$\operatorname{Prof}(a)$. $\operatorname{Dr}(a)$.

Orientador(a) 
Aos meus pais e aos meus mestres, com carinho 
“...Olha o pião do tempo com sua ponta afiada indo aprontando no quengo deste bando de guris só acredita quem souber levou um tombo e não parou de rodar veloz do lado errado da palma da nossa mão"

Gonzaguinha (Belo Balão) 


\section{Agradecimentos}

Agradeço ao Instituto de Biociências, Departamento de Botânica e Laboratório de Sistemática Vegetal pela utilização do espaço e condições para a realização deste trabalho.

Deixo aqui meu agradecimento para as agências financiadoras CAPES e CNPq, pelas bolsas concedidas durante o doutorado e o período do estágio no exterior.

Ao meu orientador, Paulo Sano, agradeço toda a confiança e preocupação depositados durante esses anos. Seus incentivos e amizade foram fundamentais em várias etapas da minha formação. Seu carinho pelas plantas, pelo ensino e pelas pessoas são inspiradores! Foi uma honra ter cruzado o seu caminho e me orgulho muito disso! "Feliz aquele que transfere o que sabe $e$ aprende o que ensina" (Cora Coralina).

Meu muito obrigado ao Field Museum of Natural History (Chicago) e ao Richard Ree e Nancy Hensold por me receberem tão bem e me deixarem tão à vontade durante minha estadia no sanduíche. Que experiência fantástica e inesquecível!

Um adendo aqui para a Nancy. Que ser apaixonante! Seu senso de humor, seu cuidado, sua dedicação foram extraordinários. Foi mais do que gratificante poder compartilhar informações das Eriocauláceas com você e poder ter aprendido tanto. Mesmo estando tão distante das plantas em seu ambiente natural, seu conhecimento sobre elas é assombroso. Foi uma honra ter te conhecido e convivido tão próximo durante esses quase dez meses.

Obrigado ao Pritzker DNA Lab (Field Museum) e toda sua equipe de técnicos. Que laboratório espetacular! Que eficiência impressionante! Meu agradecimento especial ao Kevin Feldheim, pela solicitude e empenho em resolver os obstáculos.

Um carinho especial para a Juliana Phillip, Thyana, Robin Foster, Bier e Ana Balla. O Field não teria sido o mesmo sem suas presenças.

Obrigado aos professores (Pirani, Lúcia e Renato) e técnicos (Abel, Vivi e Robertinha), do laboratório de Sistemática Vegetal que transformaram o ambiente de trabalho, em um local altamente enriquecedor, com troca de experiências, conhecimento e amadurecimento mútuo.

Um abraço bem apertado em meus amigos/colegas que mais frequentemente fizeram viagens de campo e visitas aos herbários comigo, além de me ajudarem bastante em questões práticas do dia a dia e quebra-cabeças desse doutorado: Leonardo Borges (Caqui), Matheus Santos (Bozo), Paulo Baleeiro (Baladeiro) e Juliana Rando (Ju). Feliz de mim, ter amigos como vocês. 
Suzana Alcântara $(\mathrm{Su})$ pelo incentivo permanente, amizade e por me vislumbrar a possibilidade da ponte "São Paulo - Chicago" se concretizar. Obrigado, Su!

Juliana Lovo (Ju), definitivamente Chicago não teria sido a mesma sem você. Foi um enorme prazer ter convivido com você nos EUA. Foi por pouco tempo, mas a quantidade de coisas que aprendi com você, sobre a vida e as moléculas, foi enorme! Nossos caminhos terem se cruzado no Field foi um dos acontecimentos mais marcantes desse doutorado. Um beijo no seu coração.

Aos colegas do laboratório de Sistemática Vegetal, em especial ao Luiz, Benoit, Andrino, He-man, Marcelo, "Matias", Piranha e Juzinha, que me "socorreram" em alguns momentos deste doutorado, especificamente.

Agradeço imensamente pela família que tenho, meus tios e tias, avós, madrasta e irmãos, em especial, minha irmã Nay, que ajudou a editar muitas fotos dessa tese. Tanta compreensão e paciência só poderiam mesmo partir de vocês.

Aos meus pais, que sempre investiram em minha educação, desde muito pequeno, e que talvez não imaginassem que eu pudesse alçar voos tão altos um dia. Mãe e Pai, amo vocês!!!

À Deus, por toda a magnitude que proporciona e pela beleza da vida! 


\section{Índice}

\section{Resumo Geral 01}

\section{Abstract 02 \\ Introdução Geral 03}

Capítulo 1. Novelties in Syngonanthus

Capítulo 1.1. Two new and endangered species of Syngonanthus (Eriocaulaceae) from Chapada dos Veadeiros, Goias, Brazil

Capítulo 1.2 Syngonanthus androgynus, a striking new species from South America, its phylogenetic placement and implications for evolution of bisexuality in Eriocaulaceae

Capítulo 2. Trends in Syngonanthus (Eriocaulaceae: Poales) based on molecular phylogeny: Have DNA sequences reflected morphological groups? 51

Capítulo 3 Systematics of Syngonanthus sect. Carphocephalus (Eriocaulaceae) 82

\section{Conclusões 182}




\section{Resumo Geral}

Esta tese consta de três capítulos nos quais são abordados questões relacionadas à sistemática de Syngonanthus (Eriocaulaceae). No primeiro capítulo são apresentadas novidades taxonômicas, com descrições de novas espécies do gênero, incluindo a primeira espécie de flor exclusivamente trímera e bissexual da família. No segundo capítulo, uma análise filogenética com amostragem expandida de Syngonanthus é apresentada, para tentar elucidar questões relacionadas ao posicionamento do gênero em Paepalanthoideae; verificação e sustentação de classificações infragenéricas anteriores; e correlação de grupos bem sustentados com padrões morfológicos. O último capítulo é composto por uma revisão taxonômica de Syngonanthus sect. Carphocephalus, um dos grupos morfologicamente mais complexos no gênero. A revisão constou de um total de 13 espécies, nos quais foram propostos novos sinônimos, lectotipificações e descrição de novos táxons. 


\section{Abstract}

This thesis consists of three parts involving systematics of Syngonanthus (Eriocaulaceae). The chapter I consists on taxonomic novelties, with descriptions of new species, including the first species with exclusively trimerous and bisexual flowers in the family. The second chapter is the phylogenetic study of Syngonanthus with expanded sampling This study is an attempt to clarify issues related to the placement of Syngonanthus in Paepalanthoideae; to check the support and previous infrageneric classifications; and to correlate well supported groups with morphological patterns. The chapter three consists on a taxonomic revision of Syngonanthus sect. Carphocephalus, one of the most complex groups in the genus. The revision consisted of a total of 13 species. It has been proposed new synonyms, lectotypifications and description of new taxa. 
Introdução Geral 


\section{Garacterização geral e breve histórico}

Com cerca de 1200 espécies distribuídas em 10 gêneros, Eriocaulaceae Martinov são monocotiledôneas de distribuição pantropical. Morfologicamente são bem caracterizadas pelo hábito herbáceo, geralmente apresentando uma roseta basal, de onde emergem escapos portando as inflorescências em forma de capítulo, que contêm flores unissexuais, com raríssimos casos de flores bissexuais (Giulietti \& Hensold 1990).

A primeira documentação da família foi realizada por Linneaus (1754), ao descrever Eriocaulon L. Em pouco menos de um século, a família passou por duas grandes revisões. A primeira realizada por Bongard (1831), na qual descreveu inicialmente cerca de 80 espécies em Eriocaulon. O segundo grande estudo taxonômico foi realizado por Martius (1835), que sinonimizou alguns gêneros em Eriocaulon, reconheceu o gênero monoespecífico Tonina Aubl. descrito por Aublet (1775) e descreveu os gêneros Philodice Mart. e Paepalanthus Mart. Pouco depois, Kunth (1841) descreveu Lachnocaulon Kunth, gênero restrito à América do Norte. Koërnicke (1854) realizou a segunda revisão para a família e ampliou o conhecimento das espécies neotropicais, especialmente brasileiras (Koërnicke, 1863). Além disso, descreveu Mesanthemum Koern. e classificou a família em duas tribos (Eriocaulae e Paepalanthae), acomodando os gêneros de acordo com suas afinidades morfológicas. Ruhland (1900, 1903) realizou a última grande revisão para toda a família, sugerindo mudanças taxonômicas e nomenclaturais adotadas até os dias atuais. Na ocasião, foram propostas duas subfamílias, baseando-se nas mesmas características empregadas por Koernicke (1863) para a delimitação de suas tribos e alocando os mesmos gêneros. Eriocauloideae apresentaria o número de pétalas igual ao dobro do número de estames, pétalas glandulosas e gineceu sem apêndices. Os representantes de Paepalanthoideae possuiriam número de estames igual (ou inferior) ao número de pétalas, pétalas eglandulosas e gineceu com apêndices. Os novos gêneros descritos nesta obra (Blastocaulon Ruhland, Leiothrix Ruhland e Syngonanthus Ruhland) estariam inclusos nesta última subfamília. Dentre as contribuições que se seguiram, deve-se citar Silveira (1908, 1928), que descreveu dezenas de espécies brasileiras; Herzog (1931) que descreveu Rodonanthus Herzog; Sano (2004) que elevou Actinocephalus (Koern.) Sano à categoria genérica e o recente restabelecimento de Comanthera L.B. SM (Parra \& al. 2010).

Popularmente, as Eriocaulaceae são conhecidas como "sempre-vivas" pelo fato de manterem a aparência conservada mesmo após sua retirada da natureza. A comercialização e a exportação destas plantas são estimuladas principalmente pela alta durabilidade e beleza das 
inflorescências, utilizadas para ornamentação de ambientes (Giulietti \& al. 1988) e até mesmo na confecção de acessórios (Schmidt \& al. 2007).

Dessa maneira, a importância econômica da família reside praticamente no extrativismo, que é realizado, sobretudo, em municípios localizados na Cadeia do Espinhaço (BA e MG), e que surgiu como resposta alternativa ao declínio da atividade mineradora na região. Tal movimentação econômica nas cidades envolvidas gera empregos durante todo o processo de comercialização e constitui uma importante fonte de renda para as comunidades coletoras de sempre-vivas (Giulietti \& al. 1988; Giulietti \& al. 1996). Contudo, frequentemente, as coletas de sempre-vivas acontecem de forma precoce, antes mesmo da maturação completa dos frutos, acarretando numa diminuição crítica das populações naturais. Tal exploração caótica e desenfreada levou muitas espécies ao risco iminente de extinção (Giulietti \& al. 1996), o que tem conduzido a uma série de trabalhos de conservação e conscientização com as comunidades coletoras, apoiando a adoção de formas de manejo racional (Schmidt \& al. 2007).

Quanto à distribuição pantropical da família, esta se deve, principalmente, a Eriocaulon, gênero de ampla distribuição com ca. 400 espécies, algumas ocorrendo em áreas temperadas (Giulietti \& Hensold 1990; Stützel 1998). Os demais gêneros apresentam limites mais restritos à América e/ou África, com vasta diversidade concentrada principalmente nas elevadas altitudes da Cadeia do Espinhaço (Giulietti \& al. 1987; Giulietti \& Hensold 1990), região conhecida pela riqueza dos campos rupestres e por sua alta taxa de endemismos de flora e fauna (Harley 1995), o que se verifica também nas espécies da família (Giulietti \& al. 2000). Assim, a Cadeia do Espinhaço constitui-se como o principal centro de diversidade de Eriocaulaceae, com aprox. $60 \%$ das espécies da família restritas a essa região. Outro centro de diversidade importante está localizado nas regiões dos Tepuis venezuelanos (Giulietti \& Pirani 1988).

\section{O gênero Syngonanthus}

Syngonanthus apresenta distribuição disjunta, possuindo grande diversidade de espécies nas Américas (especialmente concentradas na Cadeia do Espinhaço) além de dezoito taxa ocorrentes na África. É caracterizado pelas flores isostêmones, anteras bitecas e pétalas das flores pistiladas unidas na região mediana (Giulietti \& Hensold 1990). Ruhland (1900) descreveu o gênero a partir de espécies antes incluídas em Paepalanthus. Um sistema de classificação infragenérico também foi proposto por Ruhland (1903): tendo como referência subgêneros de Paepalanthus, o autor propôs cinco seções. A maior delas foi $S$. sect. Dimorphocaulon, sinonimizada em $S$. sect. Syngonanthus por Parra \& Giulietti (1997), por conter a espécie-tipo do gênero. Conta com 
aproximadamente 130 espécies e compreende toda distribuição geográfica do gênero (Giulietti \& Hensold 1990). Já $S$. sect Eulepis e $S$ sect. Thysanocephalus apresentam distribuição somente em países sul-americanos como Brasil, Colômbia, Guianas e Venezuela (Giulietti \& Hensold 1990) e foram recentemente re-circunscritos integrando subgêneros do restabelecido Comanthera (Parra \& al. 2010). A única espécie pertencente à S. sect. Chalarocaulon, S. macrocaulon Ruhland, foi sinonimizada em S. anomalus (Köern.) Ruhland. (S. sect. Carphocephalus) por Hensold (1999).

Syngonanthus sect. Carphocephalus também possui uma distribuição limitada à América do Sul. Nessa seção, encontra-se a espécie com a distribuição geográfica mais ampla do gênero: $S$. caulescens (Poir.) Ruhland, com pouco mais de uma dezena de variedades descritas somente para este táxon, refletindo a complexidade morfológica desse grupo. A seção é caracterizada por apresentar espécies com flores estaminadas de corola espessada e ápice involuto, além das brácteas involucrais não ultrapassando a altura das flores.

\section{A Sistemática Filogenética nos estudos de Eriocaulaceae}

Nas últimas décadas, o estudo das relações filogenéticas entre os organismos tem alcançado avanços significativos, com alterações expressivas na classificação dos táxons. A incorporação de dados moleculares às filogenias (Judd \& al. 2002) forneceu subsídios para a realização de análises mais robustas e tornaram os trabalhos taxonômicos mais consistentes. Isso se deve, em parte, à adoção dos princípios das classificações filogenéticas em que todos os táxons devem ser monofiléticos, gerando um sistema de nomes que busca refletir a filogenia em todos os níveis (Amorim 2002).

Eriocaulaceae tem passado por dinamismos em sua classificação. Anteriormente, a família era posicionada em uma ordem exclusiva (Eriocaulales) (Takhtajan 1980; Cronquist 1988) tendo como base somente os caracteres morfológicos. Estudos mais recentes, utilizando marcadores moleculares, além dos próprios dados morfológicos, têm apontado a família como um grupo monofilético demonstrando grandes afinidades com Xyridaceae (Chase \& al. 1995; Linder \& Kellogg 1995). Atualmente, está inclusa na ordem Poales (APG 2009) e estudos cladísticos na família com as mais diversas abordagens foram realizados (Giulietti \& al. 1995; Giulietti \& al. 2000; Unwin 2004). A própria condição monofilética das subfamílias já foi testada por Unwin (2004) e Andrade \& al. (2010), corroborando as hipóteses precursoras baseadas somente em dados morfológicos. Em relação aos estudos envolvendo Syngonanthus s.l., Giulietti \& al. (1995), em suas análises cladísticas com dados morfológicos, confirmaram seu monofiletismo (com a inclusão informal de Philodice) e obtiveram um bom suporte para Leiothrix como seu 
provável grupo-irmão. Giulietti \& al. (2000), com dados anatômicos e morfológicos, realizaram novas análises cladísticas com a família e, novamente, confirmaram o monofiletismo e as relações mais próximas entre Leiothrix e Syngonanthus s.l.. No mesmo trabalho, ainda foi possível observar a formação de um clado entre $S$. sect. Eulepis e $S$. sect. Thysanocephalus, sustentado por caracteres anatômicos. Estes resultados também são congruentes com os obtidos por Ricci \& al. (1996), em que fitoquimicamente $S$. sect. Eulepis e $S$. sect. Thysanocephalus têm mais afinidades por partilharem, como derivados da luteolina, os compostos C-glicosídeos, ao passo que $S$. sect. Syngonanthus e S. sect. Carphocephalus possuem compostos de 6-hidroxiluteolina. Unwin (2004) também encontrou resultados semelhantes aos anteriores, utilizando dados moleculares, porém sem grandes resoluções em relação às seções (fig.1). Entretanto, Andrade \& al. (2010), também valendo-se de marcadores moleculares, observaram que Syngonanthus constitui um grupo polifilético (fig.2), tal como circunscrito. A análise infra-genérica apontou novamente um grupo monofilético formado por $S$. sect Eulepis e $S$. sect. Thysanocephalus, como havia sido sustentado em outros trabalhos (Giulietti \& al. 2000; Parra 2000). Com base nesses resultados, foi proposto que tais seções fossem delimitadas em um novo gênero, tendo assim restabelecido o nome Comanthera (Parra \& al. 2010). S. sect. Syngonanthus, S. sect. Carphocephalus e Philodice formaram um grupo monofilético com alta sustentação. Como reflexo dos dados químicos, morfológicos e moleculares, foi proposto o reconhecimento de um único gênero: Philodice, uma vez que Syngonanthus é o nome posterior. Uma proposta de conservação do nome Syngonanthus (Giulietti \& al. 2009) foi encaminhada, levando-se em consideração que este nome é mais amplamente reconhecido na família. A proposta também envolve questões práticas, já que Philodice é um gênero monoespecífico e Syngonanthus, em sua nova circunscrição, apresentava ca. 120 espécies, o que forjaria mudanças nomenclaturais em um número muito maior de espécies. Echternarcht \& al. (2014), em uma análise filogenética mais exploratória envolvendo os gêneros Comanthera e Syngonathus, também encontrou resultados bastante consistentes a respeito da condição monofilética desses gêneros. No entanto, $S$. sect. syngonanthus revelou-se parafilética, ao passo que S. sect. Carphocephalus mostrou-se polifilética, necessitando um maior refinamento de suporte, amostragem e resolução destes grupos para maiores decisões taxonômicas. A relação entre esses dois gêneros também não foi claramente definida. Enquanto Echternacht et al. (2014) encontraram uma relação mais estreita entre Syngonanthus e Comanthera, Giulietti et al. (2012), em seus resultados, demonstraram que Syngonanthus na verdade é um gênero que divergiu primeiro em Paepalanthioideae, sendo irmão de um grande clado contendo as demais espécies da subfamília. Estas hipóteses foram testadas e são apresentadas no capítulo 2 desta tese.

Novas perspectivas têm sido cada vez mais abordadas em Eriocaulaceae e têm elucidado muitas questões com respeito à distribuição, diversificação e às afinidades filogenéticas entre os 
táxons. Trovó \& al. (2013), em estudo abrangendo toda a subfamília Paepalanthoideae com ênfase em Paepalanthus, corroborou várias hipóteses filogenéticas levantadas por Andrade \& al. (2010) e incrementou suas análises com reconstruções biogeográficas, sugerindo que os padrões de distribuição geográfica encontrados na família podem ter sido gerados por processos de vicariância e por poucos eventos de dispersão a longa distância.

Sob esta nova perspectiva e utilizando abordagens até então não utilizadas para a família como trabalhos de polinização (Ramos \& al. 2005; Oriani \& al. 2009) e morfometria (Pereira \& al. 2007; Trovó \& al. 2008; Watanabe 2009), a família tem ganhado um maior dinamismo com muitos grupos ainda por ser explorados sob as mais diversas metodologias. Dessa maneira, os estudos apresentados nessa tese pretendem elucidar algumas questões pendentes em Syngonanthus, como por exemplo: sua relação com os demais gêneros em Paepalanthoideae; as relações filogenéticas entre as espécies; delimitação e identidade de grupos no gênero; e revisão das espécies da seção Carphocephalus, um grupo morfologicamente complexo e "obscuro".

\section{Referências Bibliográficas}

Amorim, D.S. 2002. Fundamentos de Sistemática Filogenética. Ribeirão Preto: Holos.

Andrade, M.J.G.; Giulietti, A.M.; Rapini, A.; de Queiroz, L.P.; Conceição, A.S.; Almeida, P.R.M.; van den Berg, C. 2010. A comprehensive phylogenetic analysis of Eriocaulaceae; Evidence from nuclear (ITS) and plastid $(p s b \mathrm{~A}-t r n \mathrm{H}$ and $\operatorname{trn} \mathrm{L}-\mathrm{F})$ DNA sequences. Taxon 59(2): 379-388.

Angiosperms Phylogeny Group. 2009. An update of the Angiosperm Phylogeny Group classification for the orders and families of flowering plants: APG III. Bot. J. Linn. Soc. 161: 105-121.

Aublet, J. 1775. Histoire dês Plantesde La Guiane Françoise. P. F. Didot Jeune. Paris.

Bongard, M. 1831. Essai monographique sur les espéces d'Ériocaulon du Brésel. Mém Acad. Imp. Sci. St-Pétersbourg, Sér. 6, Sci Math. 1:601-655.

Chase, M.W.; Stevenson, D.W.; Wilkin, P.; Rudall, P.J. 1995. Monocot systematics: A combined analysis. PP. 685-730 in Monocotyledons: Systematics and evolution. P.J. Rudall (ed.). Royal Botanical Gardens. Kew.

Cronquist, A. 1988. The evolution and classification of flowering plants. $2^{\circ}$ ed. The New York Botanical Garden. New York.

Echternacht, L.; Sano, P.T.; Bonillo, C.; Cruaud, C.; Couloux, A.; Dubuisson, J.Y. 2014. Phylogeny and taxonomy of Syngonanthus and Comanthera (Eriocaulaceae): Evidence from expanded sampling. Taxon 63(1): 47-63. 
Giulietti, A.M.; Andrade, M.J.G.; Scatena, V.L.; Trovó, M.; Coan, A.I.; Sano, P.T.; Santos, F.A.R.; Borges, R.L.B. \& van den Berg, C. 2012. Molecular phylogeny, morphology and their implications for the taxonomy of Eriocaulaceae. Rodriguésia 63(1): 01-19.

Giulietti, A.M.; Amaral, M.C.; Bittrich, V. 1995. Phylogenetic analysis of inter and infrageneric relationships of Leiothrix Ruhland (Eriocaulaceae). Kew Bulletin 50: 55-71.

Giulietti, A.M.; Andrade, M.J.G.; Parra, L.R.; van den Berg, C.; Harley, R.M. 2009. Proposal to conserve the name Syngonanthus against Philodice (Eriocaulaceae). Táxon 58: 1008-1009.

Giulietti, N.; Giulietti, A.M.; Pirani, J.R.; Menezes, N.L. 1988. Estudos em sempre-vivas: importância econômica do extrativismo em Minas Gerais, Brasil. Acta Botanica Brasilica 1: 179-193. supl.

Giulietti, A.M.; Hensold, N. 1990. Padrões de distribuição geográfica dos gêneros de Eriocaulaceae. Acta Botanica Brasilica 4: 133-158.

Giulietti, A.M.; Menezes, N.L.; Pirani, J.R.; Meguro, M.; Wanderley, M.G.L. 1987. Flora da Serra do Cipó, Minas Gerais: caracterização e lista das espécies. Boletim de Botânica (USP) 9: $1-151$.

Giulietti, A.M.; Pirani, J.R. 1988. Patterns of geographic distribution of some plant species from the Espinhaço Range, Minas Gerais and Bahia, Brazil. In P. E. Vanzolini, (ed.). Procedings of a Workshop on Neotropical Distribution Patterns. Academia Brasiliera de Ciênicas, Rio de Janeiro.

Giulietti, A.M.; Scatena, V.L.; Sano, P.T.; Parra, L.; Queiroz, L.P.; Harley, R.M.; Menezes, N.L.; Ysepon, A.M.B.; Salatino, A.; Salatino, M.L.; Vilegas, W.; Santos, L.C.; Ricci, C.V.; Bonfim, M.C.P.; Miranda, E.B. 2000. Multidisciplinary studies on neotropical Eriocaulaceae in K. L. Wilson \& D. Morrison (eds.) Monocots: Systematics and evolution. Collingwood, CSIRO Publishing.

Giulietti, A.M.; Wanderley, M.G.L.; Longhi-Wagner, H.M.; Pirani, J.R.; Parra, L.R. 1996. Estudos em "sempre-vivas": taxonomia com ênfase nas espécies de Minas Gerais, Brasil. Acta Botanica Brasilica 10: 329-377.

Harley, R.M. 1995. Introduction in Flora of the Pico das Almas - Chapada Diamantina, Bahia, Brazil. B.L. Stannard (ed.). Kew: Royal Botanical Gardens. p. 43-78.

Hensold, N. 1999. Eriocaulaceae. Pp. 1-57. In: Berry, P.E.; Yatskievych, K. \& Holst, B.K. (eds.). Flora of Venezuelan Guayana, vol. 5. St. Louis: Missouri Botanical Garden Press.

Herzog, T. 1931. Neuer und weniger bekkante Eriocaulaceae aus Nord Brasilien und dem angrenzenden Venezuela. Feddes Repert. 20: 82-88.

Judd, W.S.; Campbell, C.S.; Kellog, E.A.; Stevens, P.F.; Donoghue, M.J. 2002. Plant Systematics: a phylogenetic approach. $2^{\circ}$ ed. Sunderland: Sinauer.

Koërnicke, F. 1854. Eriocaulacearum Monographie Supplementum. Linneana 27: 561-692.

Koërnicke, F. 1863. Eriocaulaceae in Flora Brasiliensis, vol. 3. Martius, G.P von \& Eichler, A.W. (eds.) Typographya Regia. Berlin. 
Kunth, G. 1841. Eriocaulaceae in Enumeratio Plantarum, vol. 3. Cottae, J.G. (ed.). Stuttgart.

Linder, H.P.; Kellog, E.A. 1995. Phylogenetic patterns in the Commelinid clade. Pp. 473-496 in Monocotyledons: Systematics and evolution. P.J. Rudall (ed.). Royal Botanical Gardens. Kew.

Linneaus, G. 1754. Genera Plantarum (5ed. 1960). Hafner, New York.

Martius, G.F.P. von. 1835. Die Eriocaulaceae als selbständige Pflanzefamilie aufgestelt und erläutert. Nova Acta Acad. Leop. Carol. 17: 1-72.

Oriani, A.; Sano, P.T.; Scatena, V.L. 2009. Pollination biology of Syngonanthus elegans (Eriocaulaceae - Poales). Australian Journal of Botany 57: 94-105.

Parra, L.R. 2000. Redelimitação e revisão de Syngonanthus sect. Eulepis (Bong. ex Koërn.) Ruhland (Eriocaulaceae). Tese de Doutorado. Universidade de São Paulo.

Parra, L.R.; Giulietti, A.M. 1997. Nomenclatural and taxonomic changes in Brazilian Syngonanthus (Eriocaulaceae). Wildenovia 27: 227-233.

Parra, L.R.; Giulietti, A.M.; Andrade, M.J.G.; van den Berg, C. 2010. Reestablishment and new circumscription of Comanthera (Eriocaulaceae). Táxon 59(4): 1135-1146.

Pereira, A.C.S.; Borba, E.L.; Giulietti, A.M. 2007. Genetic and morphological variability of the endangered Syngonanthus mucugensis Giul. (Eriocaulaceae) from the Chapada Diamantina, Brazil: implications for conservation and taxonomy. Botanical Journal of the Linnean Society 153: 401-416.

Ramos, G.O.G.; Borba, E.L.; Fuch, L.S. 2005. Pollination in Brazilian Syngonanthus (Eriocaulaceae) species: evidence for entomophily instead of anemophily. Annals of Botany 96: 387-397.

Ricci, G.V.; Patrício, M.G.B.; Salatino, M.L.F.; Salatino, A.; Giulietti, A.M. 1996. Flavonoids of Syngonanthus Ruhland (Eriocaulaceae): Taxonomic implications. Biochemical Systematics and Ecology 24: 577-583.

Ruhland, W. 1900. Eriocaulaceae in Urban-Symbolae Antillanae: 472-494.

Ruhland, W. 1903. Eriocaulaceae in A. Engler (ed.). Das Pflanzenreich 4(3): 1-294. Wilhelm Engelmann. Leipzig.

Sano, P.T. 2004. Actinocephalus (Koern.) Sano (Paepalanthus sect. Actinocephalus), a new genus of Eriocaulaceae, and other taxonomic and nomenclatural changes involving Paepalanthus Mart. Taxon 53: 99-107.

Schmidt, I.B.; Figueiredo, I.B.; Scariot, A. 2007. Ethnobotany and effects of harvesting on the population ecology of Syngonanyhus nitens (Bong.) Ruhland (Eriocaulaceae), a NTFP from Jalapão region, Central Brazil. Economic Botany 61(1): 73-85.

Silveira, A.A. 1908. Flora e serras mineiras. Imprensa Official. Belo Horizonte.

Silveira, A.A. 1928. Floralia montium, vol. 1. Imprensa Official. Belo Horizonte. 
Stützel, T. 1998. Eriocaulaceae. In K. Kubitzki (ed.). The families and genera of vascular plants IV. Flowering plants monocotyledons - Alismatanae and Commelinanae (except Gramineae). New York. Springer-Verlag. P. 197-207.

Takhtajan, A. 1980. Outline of the classification of flowering plants (Magnoliophyta). Botanical Review 46: 225-359.

Trovó, M.; Andrade, M.J.G.; Sano, P.T.; Ribeiro, P.L.; van den Berg, C. 2013. Molecular phylogenetics and biogeography of Neotropical Paepalanthoideae with emphasis on Brazilian Paepalanthus (Eriocaulaceae). Botanical Journal of the Linnean Society 171: 225-243.

Trovó, M.; Sano, P.T.; Winkworth, R. 2008. Morphology and environment: geographic distribution, ecological disjunction, and morphological variation in Actinocephalus polyanthus (Bong.) Sano (Eriocaulaceae). Feddes Repertorium 119: 634-643.

Unwin, M.M. 2004. Molecular systematics of Eriocaulaceae Martinov. Tese de doutorado. Miami University.

Watanabe, M.T.C. 2009. Análise morfométrica e variabilidade morfológica em populações de Syngonanthus nitens (Bong.) Ruhland (Eriocaulaceae). Dissertação de Mestrado. Universidade de São Paulo. 


\section{Chapter One}

Novelties in Syngonanthus 


\section{Chapter One: Part one}

\section{Two new and endangered species of Syngonanthus (Eriocaulaceae) from Chapada dos Veadeiros, Goiás, Brazil. ${ }^{1}$}




\begin{abstract}
We describe and illustrate two new species of Syngonanthus from Chapada dos Veadeiros (Central highlands of Brazil), an area known for its high number of endemic and threatened species, such as those described here. These species have a restricted distribution and inhabit critical areas. Syngonanthus incurvifolius has not been collected since 1994 and is critically endangered; Syngonanthus vittatus is known only from a small somewhat disturbed area, on private property, and is endangered. Evaluation of threatened status was provided by CNCFlora, the IUCN Red List Authority in Brazil.
\end{abstract}

Key words: Brazil, Cerrado, Conservation, Everlasting plants, Monocotyledons, new species, Taxonomy.

\title{
Resumo
}

Duas novas espécies de Syngonanthus são descritas para a Chapada dos Veadeiros, na região do Brasil Central. Conhecida pela grande quantidade de endemismos, esta área abriga muitas espécies ameaçadas como as descritas aqui. Não há Registro de coleta para Syngonanthus incurvifolius desde 1994, que é criticamente ameaçada de extinção; Syngonanthus vittatus é uma espécie conhecida apenas para pequenas áreas em propriedades particulares e está ameaçada. A avaliação do estado de ameaça foi provida pelo CNCFlora, a autoridade da Lista Vermelha da IUCN no Brasil.

Palavras chave: Brasil, Cerrado, Conservação, Monocotiledôneas, espécies novas, Semprevivas, Taxonomia. 


\section{Conclusion}

Probably, the new Syngonanthus species described here are closely related. The similarity in several aspects including floral attributes, vegetative characters and geographical proximity of taxa suggest close relationship, except for the different flowering times. Ongoing phylogenetic studies investigate this hypothesis (Watanabe et al. in prep.). The pilose and castaneous to reddish-brown involucral bracts are common features, shared with a small group of plants in Minas Gerais and Goiás states. These phylogenetic studies in preparation confirm that S. vittatus and $S$. densifolius var. majus are sister species, although the relationship is not clear among similar species such as S. incurvifolius, S. arenarius and S. densifolius var. brachyphyllus (Watanabe et al. in prep.).

\section{References}

Andrade, M.J.G., Giulietti, A.M., Rapini, A., Queiroz, L.P., Conceição, A.S., Almeida, P.R.M. \& van den Berg, C. (2010) A comprehensive phylogenetic analysis of Eriocaulaceae: Evidence from nuclear (ITS) and plastid (psbA-trnH and $\operatorname{trn} \mathrm{L}-\operatorname{trn} \mathrm{F})$ DNA sequences. Taxon 59: 379-388.

Echternacht, L. (2012) Sistemática de Comanthera e de Syngonanthus (Eriocaulaceae). Ph.D. Thesis, Universidade de São Paulo, São Paulo, 294 pp.

Echternacht, L., Sano, P.T. \& Dubuisson, J.-Y. (2015) Taxonomic study of Comanthera subg. Thysanocephalus (Eriocaulaceae). Systematic Botany 40(1): 136-150.

Echternacht, L., Sano, P.T., Bonillo, G., Cruaud, G., Couloux, A. \& Dubuisson, J.-Y. (2014). Phylogeny and taxonomy of Syngonanthus and Comanthera (Eriocaulaceae): evidence from expanded sampling. Taxon 63(1): 47-63.

Giulietti, AM., Scatena, V.L., Sano, P.T., Parra, L.R., Queiroz, L.P., Harley, R.M., Menezes, N.L., Benko-Yseppon, A.M., Salatino, A., Salatino, M.L., Vilegas, W., Santos, L.C., Ricci, G.V., Bonfim, M.C.P\& Miranda, E.B. (2000) Multidisciplinary studies on Neotropical Eriocaulaceae. In: Wilson, K.L. \& Morrison, D.A. (eds) Monocots II: Systematics and evolution. Melbourne: CSIRO, pp. 580-589.

Giulietti, A.M., Andrade, M.J.G. de, Scatena, V.L., Trovó, M., Coan, A.I., Sano, P.T., Santos, F. de A.R. dos, Borges, R.L.B. de \& van den Berg, C. (2012). Molecular phylogeny, morphology and their implications for the taxonomy of Eriocaulaceae. Rodriguésia 63: 1-19. 
Koernicke, F. (1854) [1856] Eriocaulacearum monographiae supplementum. Linnaea 27: 561692.

IUCN. (2001) IUCN Red List Categories and Criteria: Version 3.1. IUCN Species Survival Commission. IUCN, Gland, Switzerland \& Cambridge, UK, 70 pp.

IUCN. (2015) The IUCN red list of threatened species, Available from www.iucnredlist.org/ (accessed January 2015).

Martius, C.F.P. von. (1834) Die Eriocauleae als selbständige Pflanzenfamilie aufgestellt und erläutert. Annales des Sciences Naturelles, Botanique Ser. 2, 2: 25:43.

Moldenke, H.N (1972) Four novelties from Brazil. Phytologia 24: 498-499

Moldenke, H.N (1976) Notes on new and noteworthy plants LXXXV. Phytologia 32(6): 483-487.

Moldenke, H.N (1984) Notes on new and noteworthy plants CLXXVI. Phytologia 55: 372.

Munhoz, C.B.R. \& Felfili, J.M. (2006) Floristics of the herbaceous and subshrub layer of a moist grassland in the Cerrado biosphere reserve (Alto Paraíso de Goiás), Brazil. Edinburgh fournal of Botany 63: 343-354.

Negrão, R. (2015a). Syngonanthus incurvifolius. Lista Vermelha CNCFlora. Available from http://cncflora.jbrj.gov.br (April 15th 2015).

Negrão, R. (2015b). Syngonanthus vittatus. Lista Vermelha GNCFlora. Available from http://cncflora.jbrj.gov.br (April 15th 2015).

Parra, L.R. \& Giulietti, A.M. (1997) Nomenclatural and taxonomic changes in Brazilian Syngonanthus (Eriocaulaceae). Willdenowia 27: 227-233.

Parra, L.R., Giulietti, A.M., Andrade, M.J.G. \& van den Berg, C. (2010) Reestablishment and new circumscription of Comanthera (Eriocaulaceae). Taxon 59: 1135-1146.

Ratter, J.A., Ribeiro, J.F. \& Bridgewater, S. 1997. The Brazilian cerrado vegetation and threats to its biodiversity. Ann. Bot., vol. 80, no. 3, p. 223-230.

Ricci, G.V., Patrício, M.C.B., Salatino, M.L.F., Antônio, A. \& Giulietti, A.M. (1996) Flavonoids of Syngonanthus Ruhland (Eriocaulaceae): taxonomic implications. Biochemical Systematics and Ecology 24: 577-583.

Ruhland, W. (1900) Eriocaulaceae. In: Urban, I (ed). Symbolae Antillanae seu fundamenta florae Indiae Occidentalis 1. Borntraeger, Berlin, Klincksieck, Paris and Williams \& Norgate, London, pp. 482-494.

Ruhland, W. (1903) Eriocaulaceae. In: Engler, A. (ed.) Das Pflanzenreich IV, 30 (Heft 13). W. Engelmann, Leipzig, pp. 1-294.

Silveira, A. (1928). Floralia Montium, Imprensa Official, Belo Horizonte.

Simon, M.F., Hughes, C.E., \& Harris, S.A. (2010) Four new species of Mimosa (Leguminosae) from the Central Highlands of Brazil. Systematic Botany 35(2): 277-288. 


\section{Chapter One: Part two}

Syngonanthus androgynus, a striking new species from South America, its phylogenetic placement and implications for evolution of bisexuality in Eriocaulaceae. ${ }^{2}$

${ }^{2}$ Artigo submetido à PLoS ONE em 26 de Março de 2015. Autores: Mauricio T. C. Watanabe, Nancy Hensold \& Paulo Takeo Sano. 


\begin{abstract}
In the present study, we described and illustrated a remarkable new species of Syngonanthus from South America (records to Bolivia, Brazil and Peru). The description was based on morphological observations and comparisons, and specific literature. This new species is quickly distinguished from all species in the genus by trimerous and bisexual flowers, an exclusively set of characteristics in Syngonanthus. Complementary, sequences of 33 species were downloaded from GenBank and four species had newly generated sequences for this study. Molecular phylogenetic analyses based on nuclear ribosomal ITS and the plastids $p s b \mathrm{~A}-\operatorname{trn} \mathrm{H}$ and $\operatorname{trn} \mathrm{L}-\mathrm{F}$ regions were performed to determine its systematic position. The results have shown $S$. androgynus closely related to a well-supported clade that has been considered as Syngonanthus sect. Carphocephalus. Floral traits associated with this new plant also were surveyed. Character reconstruction has appointed that the bisexual flowers appears to be originated independently more than once in the genus. However, trimerous flowers appear to be an ancestral condition of the whole genus.
\end{abstract}




\section{Introduction}

Eriocaulaceae is a pantropical family consisting of 11 genera and approximately 1200 species $[1,2,3]$. In Brazil, various species of Eriocaulaceae have been gathered and used as dried ornamental plants for more than a century. This trade provides main and alternative income sources for hundreds of families in the Brazilian countryside [4, 5]. Most Eriocaulaceae possess unisexual and trimerous flowers, with bisexual or dimerous flowers extremely rare [6]. The inflorescences are capitulum-like composed of flowers borne on a flattened receptacle at the peduncle apex [7], with involucral bracts at the border. A single inflorescence usually has staminate and pistillate flowers in the same capitulum [1].

Syngonanthus Ruhland has been recognized as the third largest genus in Eriocaulaceae. The genus comprises approximately 120 species that exhibit a disjunct distribution in the American and African continents [1]. Some species of Syngonanthus occur in rupestrian grassland, upon shallow and sandy soils, over quartzites and sandstones, like most taxa in the Eriocaulaceae [8]. However, fieldwork observations have shown that most species of Syngonanthus inhabit marshy or poorly drained soils. The genus is distinguished by the follow character sets: isostemonous flowers, pistillate flowers with petals fused at middle and bithecous anthers (except S. cuyabensis (Bong.) Giul., Hensold \& L.R. Parra) [1]. Other characteristics are spongiose roots, nectariferous and stigmatic branches free at the same level and some species exhibit synflorescence axes.

During revisionary studies involving Syngonanthus sect. Carphocephalus, an unidentified material was selected from some herbaria in Brazil and United States of America for detailed observation. The material was shown to be surprising for its exclusively bisexual 3-parted flowers, which is the only known occurrence in this family. The goals of the present study are to describe this new remarkable taxon and check its placement in the genus. Furthermore, we have tested reconstruction of character for two characteristics of flowers in Syngonanthus.

\section{Material and Methods}

\section{Ethics Statement}

Vegetal tissue for DNA analysis was donated by major collectors or extracted from herborized materials deposited in the herbaria ANDES, INPA, F and SPF. The policies for each herbarium were followed. The samples were used only for the purpose of supporting molecular 
phylogenetics. We attest that the samples will not be available for screening for genes of interest in applied research or bioprospecting endeavors.

\section{Nomenclature}

The electronic version of this article in Portable Document Format (PDF) in a work with an ISSN or ISBN will represent a published work according to the International Code of Nomenclature for algae, fungi, and plants, and hence the new names contained in the electronic publication of a PLOS ONE article are effectively published under that Code from the electronic edition alone, so there is no longer any need to provide printed copies.

In addition, new names contained in this work have been submitted to IPNI, from where they will be made available to the Global Names Index. The IPNI LSIDs can be resolved and the associated information viewed through any standard web browser by appending the LSID contained in this publication to the prefix http://ipni.org/. The online version of this work is archived and available from the following digital repositories: PubMed Central, LOCKSS.

\section{Morphological observations}

The new species was described based on examination of pressed and rehydrated material under a stereomicroscope (Leica M125) and flowers were photographed for accurate observation (Leica DFC425). For morphological comparison, we additionally observed under stereomicroscope other Syngonanthus species with similar morphological aspect, such as S. weddellii, and Brazilian and Colombian species with bisexual flowers, dimerous flowers, such as S. amazonicus, S. trichophyllus and S. acephalus. The study also was based on information gathered in taxonomic literature, live plants in the field and other herborized materials. The material selected to be the holotype is deposited in the herbarium of University of São Paulo (SPF) and duplicates (isotypes) are deposited in Jardim Botânico do Rio de Janeiro (RB) and Instituto Brasileiro de Geografia e Estatística (IBGE). Additional specimens (paratypes) were observed in the Field Museum of Natural History (F) and Missouri Botanical Garden (MO).

\section{Sampling}

Sequences of 33 species belonging to 6 genera of Eriocaulaceae were downloaded from GenBank. Both subfamilies (Eriocauloideae and Paepalanthoideae) are represented. Additionally, sequences of four species were newly generated for this work: Syngonanthus acephalus Hensold, S. trichophyllus Moldenke, S. weddellii Moldenke and the new species. The ingroup consists of a total of 31 species, representing both sections still supported for inclusion in Syngonanthus: Syngonanthus sect. Syngonanthus and Syngonanthus sect. Carphocephalus [9, 10]. The 
Clade E shows a known strong group (PP 1, BS 96) that consists of rosette plants without synflorescence axes, such as S. minutulus, S. heteropeplus, S. costatus, S. davidsei, S. nitens, S. gracilis and S. poggeanus.

\section{Gharacter reconstruction}

Character reconstruction based on MP analyses resulted in trimerous flowers as ancestral character state for Syngonanthus ( $>$ > 99\%), with only one transition for dimerous flowers (Figure 4). This implies that 3-parted flowers proved to be the plesiomorphic state, explicitly, a shared state observed for almost all Eriocaulaceae. Dimerous flowers, a character state shared by $S$. acephalus and S. trichophyllus appears to be a synapomorphy with a unique shift in Syngonanthus. According to parsimony assignations, there is about $94 \%$ of probability for ancestral character of S. acephalus and S. trichophyllus to be represented by 2-merous flowers.

On the other hand, the bisexual condition of the flowers appears to have originated independently twice in the genus, at least. This scenario makes sense, since the bisexual-flowered species form two morphologically very distinctive groups: $S$. androgynus has 3-parted flowers and $S$. acephalus and S. trichophyllus are dimerous. The character state for type of the flowers revealed that unisexual flowers represent the ancestral character state in Syngonanthus ( $p>99 \%$ ). The bisexual condition of $S$. androgynus seems to be an isolated transition. The probability is more than $99 \%$ that unisexual flowers represent the ancestral character state in the clade $S$. androgynus / $S$. weddellii while the ancestral character state of S. acephalus and S. trichophyllus had bisexual flowers $(\mathrm{p}=88 \%)$.

\section{References}

1. Giulietti AM, Hensold N. (1990). Padrões de distribuição geográfica dos gêneros de Eriocaulaceae. Acta Botanica Brasilica 4: 133-158.

2. Trovó M, Andrade MJG, Sano PT, Ribeiro PL, Van den Berg C. (2013). Molecular phylogenetics and biogeography of Neotropical Paepalanthoideae with emphasis on Brazilian Paepalanthus (Eriocaulaceae). Bot. J. Linn. Soc. 171: 225-243

3. Echternacht L, Sano PT, Trovó M, Dubuisson JY. (2011). Phylogenetic analysis of the Brazilian microendemic Paepalanthus subgenus Xeractis (Eriocaulaceae) inferred from morphology. Bot. J. Linn. Soc. 167: 137-152. 
4. Schmidt IB, Figueiredo IB, Scariot A. (2007). Ethnobotany and effects of harvesting on the population ecology of Syngonanyhus nitens (Bong.) Ruhland (Eriocaulaceae), a NTFP from Jalapão region, Central Brazil. Economic Botany 61(1): 73-85

5. Giulietti N, Giulietti AM, Pirani JR, Menezes NL. (1988). Estudos em sempre-vivas: importância econômica do extrativismo em Minas Gerais, Brasil. Acta Botanica Brasilica 1: 179-193. supl.

6. Rosa MM, Scatena VL. (2007). Floral anatomy of Paepalanthoideae (Eriocaulaceae), Poales, and their nectariferous structures. Annals of Botany 99: 131-139.

7. Bell AD, Bryan A. (2008). Plant form: An Illustrated Guide to Flowering Plant Morphology. 2 ed. Timber Press. 432p.

8. Giulietti AM, Menezes NL, Pirani JR, Meguro M, Wanderley MGL. (1987). Flora da Serra do Cipó, Minas Gerais: caracterização e lista das espécies. Boletim de Botânica (USP) 9: 1151.

9. Ruhland W. (1903). Eriocaulaceae in A. Engler (ed.). Das Pflanzenreich 4(3): 1-294. Wilhelm Engelmann. Leipzig.

10. Parra LR, Giulietti AM, Andrade MJG, van den Berg C. (2010). Reestablishment and new circumscription of Comanthera (Eriocaulaceae). Taxon 59(4): 1135-1146.

11. Doyle JA, Doyle JL. (1987). A rapid DNA isolation procedure for small quantities of fresh leaf tissue. Phytochemistry Bulletin 19: 11-15.

12. Andrade MJG, Giulietti AM, Rapini A, de Queiroz LP, Conceição AS, Almeida PRM, van den Berg C. (2010). A comprehensive phylogenetic analysis of Eriocaulaceae; Evidence from nuclear (ITS) and plastid (psbA-trnH and trnL-F) DNA sequences. Taxon 59(2): 379-388.

13. Echternacht L, Sano PT, Bonillo C, Cruaud C, Couloux A, Dubuisson JY. (2014). Phylogeny and taxonomy of Syngonanthus and Comanthera (Eriocaulaceae): Evidence from expanded sampling. Taxon 63(1): 47-63.

14. Katoh K, Misawa K, Kuma K, Miyata T (2002) MAFFT: a novel method for rapid multiple sequence alignment based on fast Fourier transform. Nucleic Acids Res 30: 3059-3066.

15. Swofford DL (2003) PAUP*. Phylogenetic Analysis Using Parsimony (*and Other Methods). Version 4. Sunderland, Massachusetts: Sinauer Associates.

16. Ronquist F, Teslenko M, van der Mark P, Ayres DL, Darling A, Höhna S, Larget B, Liu L, Suchard MA, Huelsenbeck JP. (2012). MrBayes 3.2: Efficient Bayesian phylogenetic inference and model choice across a large model space. Systematic Biology 61:539-542.

17. Posada D. (2008). jModelTest: Phylogenetic Model Averaging. Molecular Biology and Evolution 25: 1253-1256. 


\section{Chapter Two}

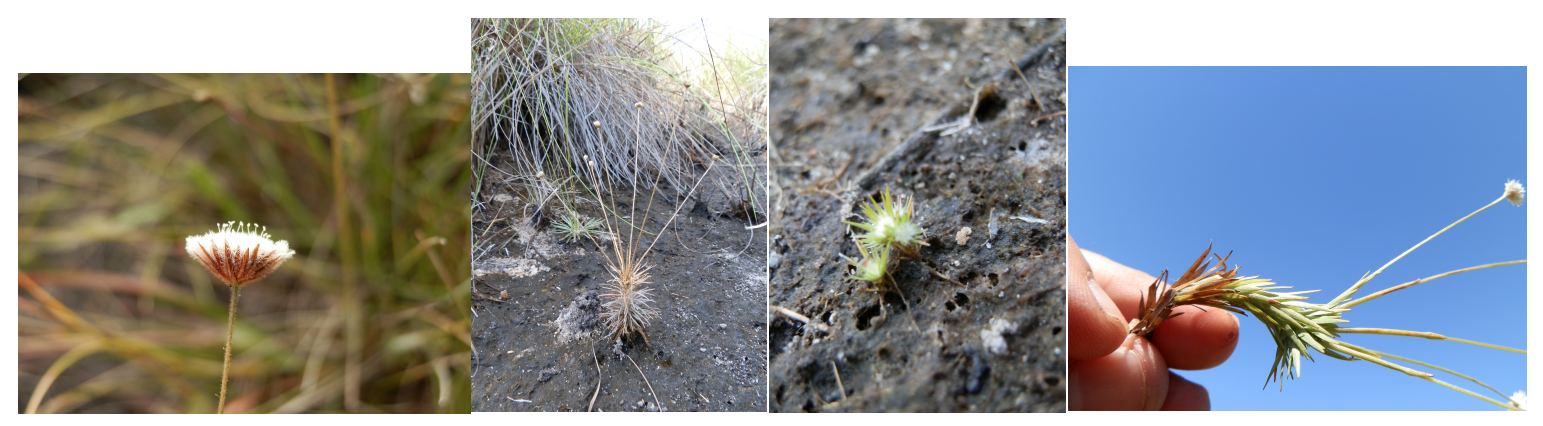

Trends in Syngonanthus (Eriocaulaceae: Poales) based on molecular phylogeny: Have DNA sequences reflected morphological groups?

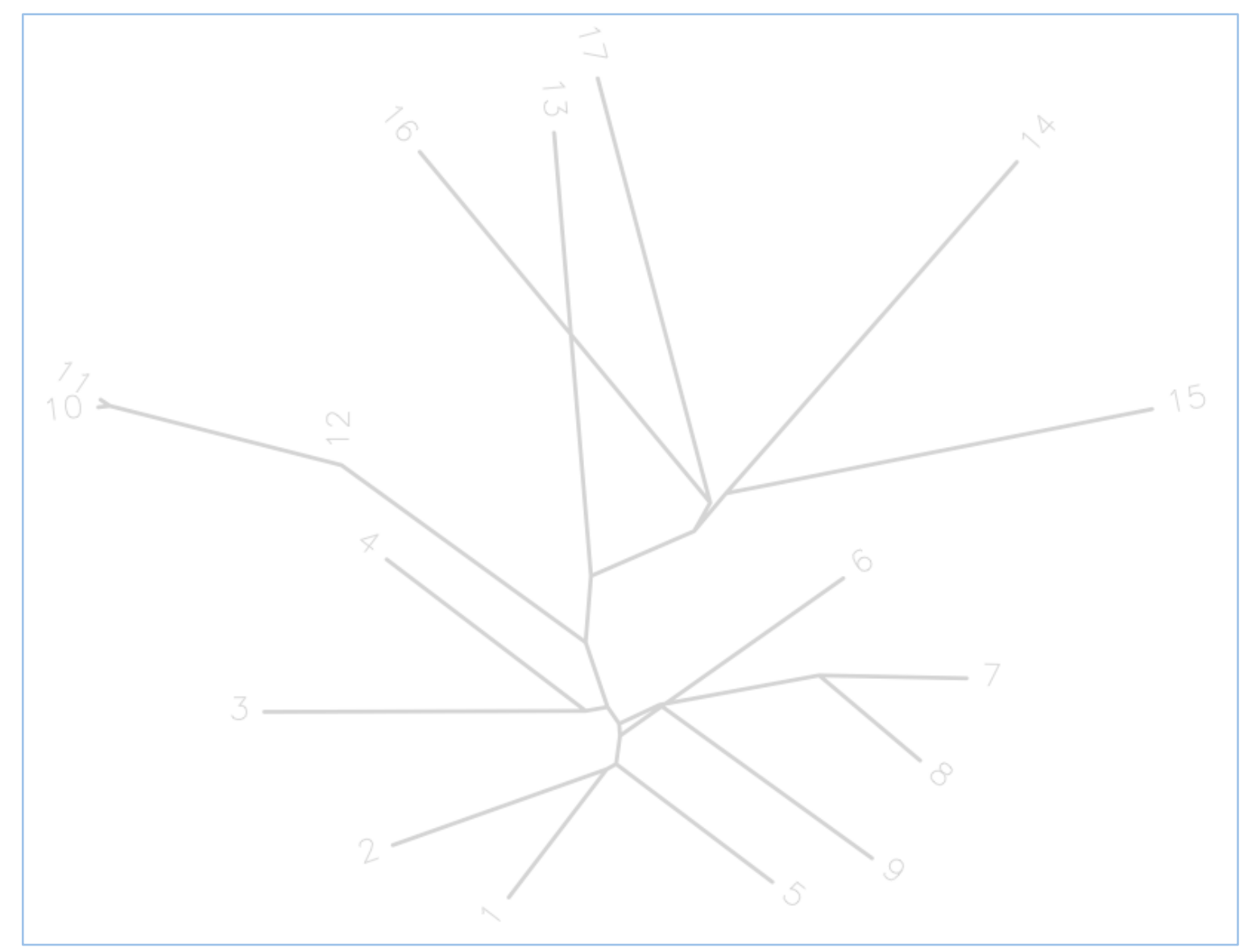




\begin{abstract}
Syngonanthus is the third largest genus in Eriocaulaceae and one of the most economically important genera in the family. Traditionally, the genus is classified in two sections: Syngonanthus sect. Syngonanthus and S. sect. Carphocephalus. Moreover, this classification is controversial due to the high levels of convergence and homoplasy of the morphological characters. In this present study, phylogenetic analyses of Syngonanthus were conducted with maximum parsimony and Bayesian analyzes using two nuclear genes (ITS and ETS) and three chloroplast regions (psbA$\operatorname{trn} \mathrm{H}, \operatorname{trn} \mathrm{L}-\mathrm{F}$ and rps 16$)$. The subjects of this study explore the placement of the genus in Paepalanthoideae, infrageneric categories and morphological groups. The results of this phylogeny study corroborated the placement of Syngonanthus as sister group of the remaining genera in Paepalanthoideae and evidenced that the traditional infrageneric groups are nonmonophyletic. Additionally, new morphological groups emerged with strong support and a new circumscription can be proposed in the future. Despite the general geographical patterns have been scarcely observed in the genus, molecular data corroborated most of morphological groups in Syngonanthus.
\end{abstract}

Keywords: Eriocaulaceae; Paepalanthoideae; phylogeny; morphology; taxonomy. 


\section{Introduction}

Eriocaulaceae is a pantropical family consisting of 11 genera and 1200 species (Giulietti \& Hensold 1990; Stützel 1998; Sano 2004; Parra et al. 2010; Andrade et al. 2011; Echternacht et al. 2011; Trovó et al. 2013). The family is characterized by herbaceous plants with compact involucrate capitula, orthotropous ovules and uniovulate locules. Most Eriocaulaceae have unisexual and trimerous flowers showing extremely rare bisexual or dimerous flowers (Rosa \& Scatena 2007; Oriani et al. 2008). A single inflorescence shows staminate and pistillate flowers (Giulietti \& Hensold 1990).

Commonly, Eriocaulaceae are known as "everlasting plants" because remain the alive appearance even after harvesting. Commercialization and exportation of these plants are primarily stimulated by the beauty and high durability of inflorescences, used for ornamental purposes (Giulietti et al. 1988) or for manufacturing accessories (Schmidt et al. 2007). However, frequently harvests of these plants are premature, before the full fruiting. This entails a critical decrease of natural populations. This chaotic scenery has left many species at imminent risk of extinction (Giulietti et al. 1996). Many conservation actions have been proposed by the scientific community, NGOs and Brazilian governmental institutions. This includes specific actions to raise awareness of the collectors and forms suitable of management. Several species of Syngonanthus Ruhland (Paepalanthoideae) are covered by these goals, such as Syngonanthus nitens (Bong.) Ruhland (common name "golden grass"), Syngonanthus niger Silveira, Syngonanthus macrolepis Silveira, among others species of the genus.

Syngonanthus has been recognized as the third largest genus in Eriocaulaceae. The genus comprises about 120 species, which exhibit a disjunction distribution in American and African continents (Giulietti \& Hensold 1990). Only about a sixth of Syngonanthus occurs in Africa (Phillips, 1997). The most of the diversity is concentrated in Eastern Brazil mainly in Espinhaço range. This region has high elevations (above $900 \mathrm{~m}$ ) and rich mountaintop endemisms of fauna and flora (Giulietti et al. 1987; Harley 1995; Giulietti et al. 2000). Giulietti \& Pirani (1988) claim that about 60 percent of species in Eriocaulaceae occur in this area, and Venezuelan tepuis have been reported as another rich endemism area to Eriocaulaceae (Hensold 1999). Some species in the Syngonanthus genera occur in ruspestrian grassland, up shallow and Sandy soils, and rocks quartzites and sandstones, like in the most taxa in Eriocaulaceae (Giulietti et al. 1987). However, fieldwork observations have shown that the most species of Syngonanthus inhabit marshy or easily water drainage soils. 
Syngonanthus is distinguished by the follow character sets: isostemonous flowers, bitec anthers (except S. cuyabensis and S. infimus) and pistillate flowers with fusioned petals at middle (Giulietti \& Hensold 1990). Others characteristics are spongiate roots, nectariferous and stigmatic branches free at the same level and some species exhibit sinflorescence axis. Ruhland (1900) described the genus from taxa previously included in Paepalanthus. Subsequently, an infrageneric classification was also proposed by Ruhland (1903). Taking the reference point a subgenus of Paepalanthus, the author proposed five sections. The largest section was Syngonanthus sect. Dimorphocaulon, synonymized with Syngonanthus sect. Syngonanthus by Parra \& Giulietti (1997). This section has about 130 species and includes all geographical distribution of the genus (Giulietti \& Hensold 1990). Recently, Syngonanthus sect Eulepis and Syngonanthus sect. Thysanocephalus were recircumscribed and transferred to the reestablished Comanthera (Parra \& al. 2010), that presents restricted geographical distribution in South America, including Brazil, Colombia, Guyana and Venezuela (Giulietti \& Hensold 1990). Syngonanthus sect. Chalarocaulon and S. macrocaulon Ruhland were synonymized with S. anomalus (Köern.) Ruhland. (S. sect. Carphocephalus) by Hensold (1999). The current circumscription of $S$. sect. Carphocephalus is restricted to approximately 15 species; most of all is rare or not seen in natural fields.

The goals of the present study are to expand a phylogenetic analyzes of Syngonanthus with a broader taxon sampling and an increased number of molecular markers, a total of five. All studies conducted with Eriocaulaceae at this moment have used only $p s b \mathrm{~A}-\operatorname{tr} \mathrm{H}, \operatorname{trn} \mathrm{L}-\mathrm{F}$ and ITS regions. Furthermore, we are investigating the circumscription of the sections currently accepted: Syngonanthus sect. Syngonanthus and Syngonanthus sect. Carphocephalus; and to check other infrageneric relationships.

\section{Materials and Methods}

\subsection{Taxon sampling}

In this study, a total of 111 accessions belonging to 77 Syngonanthus taxa (ingroup) were included in the analyzes (table 1), in order to cover the morphological diversity and geographical distribution of the genus. We covered the complete geographical distribution of the genus with representative taxa from Africa and North, Central and South America. Most of taxa were collected in Brazil but some of that species occur in South and/or Central America (e.g. S. davidsei, S. caulescens, S. trichophyllus and S. heteropeplus, for detailed information see table 2). The traditional subdivision of the genus also had covered with species from Syngonanthus sect. Syngonanthus and Syngonanthus sect. Carphocephalus (Ruhland 1903; Andrade et al. 2010; 
necessary to investigate and ascertain whether these features have relationship with ecological attraction of pollinator or evolutionary aspects.

Syngonanthus is a promising model for evolutionary research, because it has the most morphological diversity in Eriocaulaceae, along with Paepalanthus. Much of this richness and diversity of species is concentrated in specific areas, such as mountains of Espinhaço range and Central Brazil. Moreover, this morphological diversity is associated with molecular data, and morphological groups are corroborated by phylogenetic analyses.

\section{References}

Andrade, M.J.G., Giulietti, A.M., Rapini, A., de Queiroz, L.P., Conceição, A.S., Almeida, P.R.M., van den Berg, C. 2010. A comprehensive phylogenetic analyzes of Eriocaulaceae; Evidence from nuclear (ITS) and plastid ( $p s b \mathrm{~A}-t r n \mathrm{H}$ and $t r n \mathrm{~L}-\mathrm{F})$ DNA sequences. Taxon 59(2): 379-388.

Andrade, M.J.G., Giulietti, A.M., Harley, R.M., van den Berg, G. 2011. Blastocaulon (Eriocaulaceae), a synonym of Paepalanthus: morphological and molecular evidence. Taxon 60: 178-184.

Cummings, M.P., Handley, S.A., Myers, D.R., Reed, D.L., Rokas, A. \& Winka, K. 2003. Comparing bootstrap and posterior probability values in the four-taxon case. Systematic Biology 52: 477-487.

Desfeaux, C., S. Maurice, J. P. Henry, B. Lejeune, and P. H. Gouyon. 1996 . The evolution of reproductive system in the genus Silene . Proceedings: Biological Sciences 263: 409-414 .

Doyle, J.A., Doyle, J.L. 1987. A rapid DNA isolation procedure for small quantities of fresh leaf tissue. Phytochemistry Bulletin 19: 11-15.

Drummond, A.J., Ashton, B., Buxton, S., Cheung, M., Cooper, A., Duran, G., Field, M., Heled, J., Kearse, M., Markowitz, S., Moir, R., Stones-Havas, S., Sturrock, S., Thierer, T., Wilson, A. 2011. Geneious v5.4. Available from http://www.geneious.com/

Echternacht, L., Sano, P.T., Trovó, M., Dubuisson, J.-Y. 2011. Phylogenetic analyzes of the Brazilian microendemic Paepalanthus subgenus Xeractis (Eriocaulaceae) inferred from morphology. Bot. J. Linn. Soc. 167: 137-152.

Echternacht, L., Sano, P.T., Bonillo, C., Cruaud, G., Couloux, A. \& Dubuisson, J.-Y. 2014. Phylogeny and taxonomy of Syngonanthus and Comanthera (Eriocaulaceae): evidence from expanded sampling. Taxon 63(1): 47-63.

Giulietti, A.M., Menezes, N.L., Pirani, J.R., Meguro, M., Wanderley, M.G.L. 1987. Flora da Serra do Cipó, Minas Gerais: caracterização e lista das espécies. Boletim de Botânica (USP) 9: 1-151.

Giulietti, A.M.; Pirani, J.R. 1988. Patterns of geographic distribution of some plant species from the Espinhaço Range, Minas Gerais and Bahia, Brazil. In P. E. Vanzolini, (ed.). Procedings of a Workshop on Neotropical Distribution Patterns. Academia Brasiliera de Ciênicas, Rio de Janeiro.

Giulietti, A.M., Hensold, N. 1990. Padrões de distribuição geográfica dos gêneros de Eriocaulaceae. Acta Botanica Brasilica 4: 133-158. 
Giulietti, A.M., Wanderley, M.G.L., Longhi-Wagner, H.M., Pirani, J.R., Parra, L.R. 1996. Estudos em "sempre-vivas": taxonomia com ênfase nas espécies de Minas Gerais, Brasil. Acta Botanica Brasilica 10: 329-377.

Giulietti, A.M., Scatena, V.L., Sano, P.T., Parra, L., Queiroz, L.P., Harley, R.M., Menezes, N.L., Ysepon, A.M.B., Salatino, A., Salatino, M.L., Vilegas, W., Santos, L.C., Ricci, G.V., Bonfim, M.C.P., Miranda, E.B. 2000. Multidisciplinary studies on neotropical Eriocaulaceae. Pp: 580-589 in: K. L. Wilson \& D. Morrison (eds.) Monocots: Systematics and evolution. Collingwood, CSIRO Publishing. Giulietti, A.M., Andrade, M.J.G. de, Scatena, V.L., Trovó, M., Goan, A.I., Sano, P.T., Santos, F. de A.R. dos, Borges, R.L.B. de \& van den Berg, C. 2012a. Molecular phylogeny, morphology and their implications for the taxonomy of Eriocaulaceae. Rodriguésia 63: 1-19.

Giulietti, A.M., Hensold, N, Parra, L.R., Andrade, M.J.G., Scatena, Van den Berg, G., Harley, R.M. 2012b. The synonymization of Philodice in Syngonanthus (Eriocaulaceae). Phytotaxa 60: 50-56

Harley, R.M. 1995. Introduction in Flora of the Pico das Almas - Chapada Diamantina, Bahia, Brazil. B.L. Stannard (ed.). Kew: Royal Botanical Gardens. p. 43-78.

Hensold, N. 1999. Eriocaulaceae. Pp. 1-57. In: Berry, P.E., Yatskievych, K., Holst, B.K. (eds.). Flora of Venezuelan Guayana, vol. 5. St. Louis: Missouri Botanical Garden Press.

Hensold, N., Oliveira, A.L.R., Giulietti, A.M. 2012. Syngonanthus restingensis (Eriocaulaceae): a remarkable new species endemic to Brazilian coastal shrublands. Phytotaxa 40: 1-11.

Katoh K., Misawa K., Kuma K., Miyata T. 2002. MAFFT: a novel method for rapid multiple sequence alignment based on fast Fourier transform. Nucleic Acids Res 30: 3059-3066.

Koërnicke, F. 1863. Eriocaulaceae in Flora Brasiliensis, vol. 3. Martius, G.P von \& Eichler, A.W. (eds.) Typographya Regia. Berlin.

Linder, G.R., Goertzen, L.R., Heuvel, B.V., Francisco-Orgega, J., Jansen, R. 2000. The complete external transcribed spacer of $18 \mathrm{~S}-26 \mathrm{~S}$ rDNA: amplification and phylogenetic utility at low taxonomic levels in Asteraceae and closely allied families. Molecular Phylogenetics and Evolution 14: 285-303.

Oriani, A., Scatena, V.L., Sano, P.T. 2008. Morphological architecture of Actinocephalus (Koern.) Sano (Eriocaulaceae). Flora 203: 341-349.

Oxelman B. Lidén M.. 1995. Generic boundaries in the tribe Sileneae (Caryophyllaceae) as inferred from nuclear rDNA sequences. Taxon 44: 525-542

Parra, L.R.; Giulietti, A.M. 1997. Nomenclatural and taxonomic changes in Brazilian Syngonanthus (Eriocaulaceae). Wildenovia 27: 227-233.

Parra, L.R., Giulietti, A.M., Andrade, M.J.G., van den Berg, C. 2010. Reestablishment and new circumscription of Comanthera (Eriocaulaceae). Taxon 59(4): 1135-1146.

Phillips, S.M. 1997. The genus Syngonanthus (Eriocaulaceae) in eastern and southern Africa. Kew Bull. 52: 73-89.

Posada, D. 2008. jModelTest: Phylogenetic Model Averaging. Molecular Biology and Evolution 25: 1253-1256. 
Rambaut A, Drummond AJ, (2007). Tracer: Available at: <http://beast.bio.ed.ac.uk/tracer>. (accessed 22 December 2014).

Ronquist F., Teslenko M., van der Mark P., Ayres D.L., Darling A., Höhna S., Larget B., Liu L., Suchard M.A., Huelsenbeck J.P. 2012. MrBayes 3.2: Efficient Bayesian phylogenetic inference and model choice across a large model space. Systematic Biology 61:539-542.

Rosa, M.M., Scatena, V.L. 2007. Floral anatomy of Paepalanthoideae (Eriocaulaceae), Poales, and their nectariferous structures. Annals of Botany 99: 131-139.

Ruhland, W. 1900. Eriocaulaceae in Urban-Symbolae Antillanae: 472-494.

Ruhland, W. 1903. Eriocaulaceae in A. Engler (ed.). Das Pflanzenreich 4(3): 1-294. Wilhelm Engelmann. Leipzig.

Sang, T., Crawford, D. J., and Stuessy, T. F. (1997a). Chloroplast DNA phylogeny, reticulate evolution, and biogeography of Paeonia (Paeoniaceae). Am. F. Bot. 84: 1120-1136

Sano, P.T. 2004. Actinocephalus (Koern.) Sano (Paepalanthus sect. Actinocephalus), a new genus of Eriocaulaceae, and other taxonomic and nomenclatural changes involving Paepalanthus Mart. Taxon 53: 99-107.

Schmidt, I.B., Figueiredo, I.B., Scariot, A. 2007. Ethnobotany and effects of harvesting on the population ecology of Syngonanyhus nitens (Bong.) Ruhland (Eriocaulaceae), a NTFP from Jalapão region, Central Brazil. Economic Botany 61(1): 73-85.

Simmons, M.P., Pickett, K.M. \& Miya, M. 2004. How meaningful are Bayesian support values? Molecular Biology and Evolution 21: 188-199.

Stützel, T. 1998. Eriocaulaceae. In K. Kubitzki (ed.). The families and genera of vascular plants IV. Flowering plants monocotyledons - Alismatanae and Commelinanae (except Gramineae). New York. Springer-Verlag: 197-207.

Swofford, D.L. 2003. PAUP*. Phylogenetic Analysis Using Parsimony (*and Other Methods). Version 4. Sunderland, Massachusetts: Sinauer Associates.

Tarberlet P, Gielly L, Pautou G et al., 1991. Universal primers for amplification of the three noncoding regions of chloroplast DNA. Plant Molacular Biology, 17: 1105-1109

Trovó, M., Andrade, M.J.G., Sano, P.T., Ribeiro, P.L., Van den Berg, C. 2013. Molecular phylogenetics and biogeography of Neotropical Paepalanthoideae with emphasis on Brazilian Paepalanthus (Eriocaulaceae). Bot. J. Linn. Soc. 171: 225-243 


\section{Chapter three}

Systematics of Syngonanthus sect. Carphocephalus (Eriocaulaceae) 


\section{Resumo}

Apresentamos aqui a revisão taxonômica de Syngonanthus sect. Carphocephalus (Eriocaulaceae), com ênfase na morfologia do grupo. O estudo é baseado na análise de materiais de herbário e em observações de campo. Esta seção consta de 12 espécies localmente restritas ao continente americano, com espécies de ampla distribuição, como S. caulescens, mas também espécies raras ou conhecidas apenas pelo material-tipo, caso de S. cachimboensis. A seção é caracterizada por plantas de caule aéreo desenvolvido, recoberto por folhas dispostas espiraladamente, com inflorescências sempre apicais e também pelas pétalas crassas das flores estaminadas. Todas as espécies são trímeras e possuem flores unissexuais, com exceção da nova espécie aqui descrita (S. androgynus), que possui flores bissexuais. Os taxa possuem morfologia bastante semelhante, o que torna a taxonomia deste grupo um tanto complexa. Syngonanthus ruhlandii é um exemplo dessa realidade: esta espécie, restrita ao extremo oeste da Bahia, é distinguida de $S$. caulescens com base em dados moleculares e sutis caracteres fenotípicos. As espécies podem ser reconhecidas principalmente pela disposição e forma das folhas no caule aéreo, pela forma das brácteas involucrais e por caracteres florais como ausência/presença/redução dos apêndices. Os espécimes geralmente ocorrem em locais úmidos, como veredas, brejos e campos úmidos, principalmente no Brasil. Somente três espécies possuem ocorrência extra-brasileira, casos de $S$. androgynus, $S$. caulescens e $S$. peruvianus. Devido aos escassos registros nos herbários e à restrita extensão geográfica de alguns taxa, a maioria das espécies foi categorizada como criticamente ameaçada de extinção. Neste tratamento taxonômico, são apresentadas descrições para a seção e suas espécies, comentários, chave de identificação, mapas, ilustrações botânicas e fotografias. Paralelamente, algumas questões relacionadas à nomenclatura também foram verificadas, com indicação de lectótipos, novas sinonimizações e mudança de status.

Palavras chave: Taxonomia; Syngonanthus; Cerrado; Paepalanthoideae; Espécies raras; Savanas; Espécies novas. 


\begin{abstract}
A revisionary study of Syngonanthus sect. Carphocephalus (Eriocaulaceae) with emphasis on its morphology is presented here. This study is based on thorough analyses of herborized materials and field observations. The section contains 12 species, all restricted to South, Central and North America. Some species are widely distributed, such as S. caulescens, but most are rare or only known from the holotype (as in the case S. cachimboensis). Plants are characterized by welldeveloped aerial stems with leaves spirally distributed, apical inflorescences, and petals of staminate flowers thickened, at least partially. Generally, the flowers are 3-merous and unisexual as in most Eriocaulaceae, except for $S$. androgynus (a new species described with bisexual flowers). The species have a similar morphology making their identification difficult. Taxa can be distinguished by arrangement and form of leaves on aerial stem, form of involucral bracts and floral traits such as appendages present/absent/reduced. Populations occur in wetlands, "veredas" and swamps, mainly in Brazil. Only three species occur in extra-Brazilian territory $(S$. androgynus, S. caulescens and S. peruvianus). Due to scarce records in herbaria and restricted geographical distribution, most species were categorized as endangered or critically endangered. This taxonomic treatment presents detailed descriptions to $S$. sect. Carphocephalus and species included, commentaries, identification keys, maps, line drawings and photos. Additionally, nomenclatural issues also have been checked and some lectotype selections, new synonyms and change of status are reported.
\end{abstract}

Keywords: Taxonomy; Syngonanthus; Cerrado; Paepalanthoideae; Rare Species; Savanas; New Species. 
our circumscription. S. anomalus does not share characteristics of $S$. sect. Carphocephalus, especially those of the "core group", as petals of pistillate flowers carnose in the lower half, exclusively terminal inflorescences and sepals slightly thickened in the upper half. The corolla of staminate flower is rigid, not spongy. The convergence of characteristics is homoplastic for many characters in Syngonanthus and it may be an example of this.

Syngonanthus philodicoides (Koern.) Ruhland in Engler, Pflanzenr. 13 (IV.30): 266. 1903. Paepalanthus philodicoides Koern., in Fl. Bras. (Martius) 3(1): 469. 1863. Dupatya philodicoides (Koern.) Kuntze, Revis. Gen. Pl. 2: 746. 1891. Type: Brazil. Goiás: In prov. Goyazensis campis arenosis humidis prope Salinas, H.A. Weddell 2126 (Syntypes: P BR, P, NY!).

Notes: Koenicke (1863) described this species and S. anomalus in Paepalanthus subg. Carphocephalus because these taxa have staminate flowers with a carnose corolla. Ruhland (1903) transferred these

species to Syngonanthus in S. sect. Carphocephalus, basically following the concepts adopted by Koernicke (1863). Syngonanthus philodicoides is morphologically similar to species belonging to a new emergent clade in our phylogenetic study (see chapter 2), the "Philodice group". Species in this clade have flowers with corolla not involute after anthesis and petals of pistillate flowers with lower half membranous and upper half carnose.

\section{References}

Andrade, M.J.G.; Giulietti, A.M.; Rapini, A.; de Queiroz, L.P.; Conceição, A.S.; Almeida, P.R.M.; van den Berg, C. 2010. A comprehensive phylogenetic analysis of Eriocaulaceae; Evidence from nuclear (ITS) and plastid (psbA-trnH and trnL-F) DNA sequences. Taxon 59(2): 379-388.

Bongard, M. 1831. Essai monographique sur les espèces d'Ériocaulon du Brésil. Mém Acad. Imp. Sci. St-Pétersbourg, Sér. 6, Sci Math.: 601-655.

Brummitt, R.K.; Powell, C.E. 1992. Authors of Plant Names. Royal Botanic Gardens, Kew. 732p.

Davis, P.H.; Heywood, V.H. 1963. Principles of Angiosperms Taxonomy. New Jersey, NY: Van Nostrand. Princeton.

Echternacht, L. 2012. Sistemática de Comanthera e de Syngonanthus (Eriocaulaceae). Ph.D. Thesis, Universidade de São Paulo, São Paulo, 294 pp. 
Echternacht, L.; Sano, P.T.; Bonillo, G.; Cruaud, C.; Couloux, A.; Dubuisson, J.Y. 2014. Phylogeny and taxonomy of Syngonanthus and Comanthera (Eriocaulaceae): Evidence from expanded sampling. Taxon 63(1): 47-63.

Giulietti, A.M.; Hensold, N. 1990. Padrões de distribuição geográfica dos gêneros de Eriocaulaceae. Acta Botanica Brasilica 4: 133-158.

Giulietti, A.M.; Amaral, M.C.; Bittrich, V. 1995. Phylogenetic analysis of inter and infrageneric relationships of Leiothrix Ruhland (Eriocaulaceae). Kew Bulletin 50: 55-71.

Giulietti, A.M.; Scatena, V.L.; Sano, P.T.; Parra, L.; Queiroz, L.P.; Harley, R.M.; Menezes, N.L.; Ysepon, A.M.B.; Salatino, A.; Salatino, M.L.; Vilegas, W.; Santos, L.C.; Ricci, C.V.; Bonfim, M.C.P.; Miranda, E.B. 2000. Multidisciplinary studies on neotropical Eriocaulaceae in K. L. Wilson \& D. Morrison (eds.) Monocots: Systematics and evolution. Collingwood, CSIRO Publishing.

Giulietti, A.M.; Andrade, M.J.G.; Parra, L.R.; van den Berg, C.; Harley, R.M. 2009. Proposal to conserve the name Syngonanthus against Philodice (Eriocaulaceae). Táxon 58: 1008-1009.

Giulietti, A.M., Hensold, N.; Parra, L.R.; Andrade, M.J.G.; van den Berg, C.; Harley, R.M. $2012 a$. The synonymization of Philodice in Syngonanthus (Eriocaulaceae). Phytotaxa 60: 50-56.

Giulietti, A.M.; Andrade, M.J.G.; Scatena, V.L.; Trovó, M.; Coan, A.I.; Sano, P.T.; Santos, F.A.R.; Borges, R.L.B.; van den Berg, C. 2012b. Molecular phylogeny, morphology and their implications for the taxonomy of Eriocaulaceae. Rodriguésia 63: 1-19

Goodman, E.J. 1972. The explorers of South America. New York: Macmillan.

Hensold, N. 1988. Morphology and Systematics of Paepalanthus subgenus Xeractis (Eriocaulaceae). In: The American Society of Plant Taxonomists (eds.), Systematic Botany Monographs, vol. 23. Ann Arbor, Michigan. pp. 1-150

Hensold, N. 1991. Revisionary Studies in the Eriocaulaceae of Venezuela. Ann. Mo. Bot. Gard. 78: 424-440.

Hensold, N. 1999. Eriocaulaceae. Pp. 1-57. In: Berry, P.E.; Yatskievych, K. \& Holst, B.K. (eds.). Flora of Venezuelan Guayana, vol. 5. St. Louis: Missouri Botanical Garden Press.

IUCN Standards and Petitions Subcommittee. 2014. Guidelines for Using the IUCN Red List Categories and Criteria. Version 11. Prepared by the Standards and Petitions Subcommittee. Downloadable from http://www.iucnredlist.org/documents/RedListGuidelines.pdf.

Koërnicke, F. 1863. Eriocaulaceae in Flora Brasiliensis, vol. 3. Martius, G.P von \& Eichler, A.W. (eds.) Typographya Regia. Berlin. 
Moldenke, H.N. 1941. New or Noteworth South American Eriocaulaceae. Bulletin of the Torrey Botanical Club 68: 67-70.

Moldenke, H.N. 1951. Eriocaulaceae. Pp. 114-129. In: Steyermark J. (ed.), Botanical exploration in Venezuela. Fieldiana Bot. 28.

Moldenke, H.N. 1973. Notes on new and noteworthy plants LIX. Phytologia 26: 177-179.

Moldenke, H.N. 1977. Additional notes on the Eriocaulaceae LXIX. Phytologia 35(5): 364.

Oriani, A.; Sano, P.T.; Scatena, V.L. 2009. Pollination biology of Syngonanthus elegans (Eriocaulaceae - Poales). Australian Journal of Botany 57: 94-105.

Parra, L.R.; Giulietti, A.M. 1997. Nomenclatural and taxonomic changes in Brazilian Syngonanthus (Eriocaulaceae). Willdenowia 22: 227-233.

Parra, L.R.; Giulietti, A.M.; Andrade, M.J.G.; van den Berg, C. 2010. Reestablishment and new circumscription of Comanthera (Eriocaulaceae). Táxon 59(4): 1135-1146.

Phillips, S. M. 1997. The genus Syngonanthus (Eriocaulaceae) in eastern and southern Africa Kew Bulletin 52: 73-89.

Poiret, J.L.M. 1813. Encyclopedie Methodique. Botanique [J. Lamarck \& al.] Suppl. 3: 162.

Radford, A.E.; Dickison, W.C.; Massey, J.R.; Bell, C.R. 1974. Vascular Plant Systematics. Harper \& Row Publishers, New York. 891pp.

Ramos, G.O.C.; Borba, E.L.; Fuch, L.S. 2005. Pollination in Brazilian Syngonanthus (Eriocaulaceae) species: evidence for entomophily instead of anemophily. Annals of Botany 96: 387-397.

Ricci, G.V.; Patrício, M.C.B.; Salatino, M.L.F.; Salatino, A.; Giulietti, A.M. 1996. Flavonoids of Syngonanthus Ruhland (Eriocaulaceae): Taxonomic implications. Biochemical Systematics and Ecology 24: 577-583.

Ruhland, W. 1900. Eriocaulaceae in Urban-Symbolae Antillanae: 472-494.

Ruhland, W. 1903. Eriocaulaceae in A. Engler (ed.). Das Pflanzenreich 4(3): 1-294. Wilhelm Engelmann. Leipzig.

Sanches, R.A.; Rossete, A.N.; Rezende, A.G.P.; Alves, H.Q.; Villas-Bôas, A. 2012. Subsídios para a proteção de áreas úmidas da bacia do rio Xingu (Mato Grosso, Brasil). Revista Árvore 36(3): 489-498.

Scatena, V.L.; Menezes, N.L. 1996. Anatomia de raízes de Syngonanthus Ruhl. (Eriocaulaceae). Rev. Bras. Biol. 56: 333-343. 
Scatena, V.L.; Giulietti, A.M.; Borba, E.L.; van den Berg, C. 2005. Anatomy of Brazilian Eriocaulaceae: correlation with taxonomy and habitat using multivariate analyses. Plant Syst. Evol. 253: 1-22.

Stearn, W.T. 1992. Botanical Latin. David \& Charles, Timber Press, Portland.

Thiers, B. 2014. Index herbariorum: a global directory of public herbaria and associated staff. New York Botanical Garden's Virtual Herbarium.

Trovó, M. 2010. Systematics of Paepalanthoideae (Eriocaulaceae): phylogeny, morphology, and taxonomy of Diphyomene (Ruhland) Trovó. Ph.D. thesis, Universidade de São Paulo, São Paulo.

Trovó, M.; Andrade, M.J.G.; Sano, P.T.; Ribeiro, P.L.; van den Berg, C. 2013. Molecular phylogenetics and biogeography of Neotropical Paepalanthoideae with emphasis on Brazilian Paepalanthus (Eriocaulaceae). Botanical Journal of the Linnean Society 171: 225-243.

Trovó, M.; Echternacht, L.; Costa, F.N.; Giulietti, A.M.; Sano, P.T. 2015. Nomenclatural and Taxonomic Notes on Eriocaulaceae from the Atlantic Forest, Brazil. Phytotaxa 205(4): 249-258.

Trovó, M.; Echternacht, L.; Costa, F.N.; Watanabe, M.T.G.; Sano, P.T. 2014. Nomenclatural and Taxonomic novelties in Eriocaulaceae from the states of Rio Janeiro and Santa Catarina, Brazil. Phytotaxa 162(4): 217-222.

Trovó, M.; Stützel, T. 2011. Diaspores in Eriocaulaceae: morphology, mechanisms, and implications. Feddes Repertorium 122(7-8): 456-464.

Wurdack, J.J. 1970. Erroneous data in Glaziou collections of Melastomataceae. Taxon 19(6): 911913. 


\section{Conclusões}

As espécies descritas no primeiro capítulo foram de fundamental importância para o estudo taxonômico do grupo e entendimento de padrões no gênero. Syngonanthus androgynus, a nova espécie descrita no capítulo 1.2, foi a primeira espécie com flores exclusivamente trímeras e bissexuais na família, o que nos levou a concluir que a evolução de flores bissexuais no gênero ocorreu, pelo menos, mais de uma vez. A filogenia de Syngonanthus com uma amostragem expandida, abrangendo uma maior variabilidade morfológica e geográfica do gênero (capítulo 2), alterou o cenário até então desenhado recentemente para Eriocaulaceae. Neste estudo, Syngonanthus emergiu como um gênero monofilético e em uma linhagem completamente diferente dos demais gêneros de Paepalanthoideae, sendo grupo-irmão dos demais gêneros reunidos. Este estudo também mostrou que classificações infragenéricas históricas não se sustentam e novas circunscrições são necessárias. Por fim (capítulo 3), uma dessas propostas é posta em prática, com uma delimitação mais precisa para Syngonanthus sect. Carphocephalus, numa tentativa de reestabelecer a condição monofilética do grupo. Nesta revisão, duas novas espécies são apresentadas e um táxon tem seu status alterado. Também são apresentados novos sinônimos e lectotipificações. 